Feminist Debates 
Also by Valerie Bryson

Feminist Political Theory: An Introduction 


\title{
Feminist Debates
}

\section{Issues of Theory and Political Practice}

\author{
Valerie Bryson
}

Consultant editor: Jo Campling 


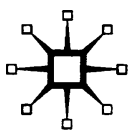

(C) Valerie Bryson 1999

Softcover reprint of the hardcover 1st edition 1999 978-0-333-61339-9

All rights reserved. No reproduction, copy or transmission of this publication may be made without written permission.

No paragraph of this publication may be reproduced, copied or transmitted save with written permission or in accordance with the provisions of the Copyright, Designs and Patents Act 1988, or under the terms of any licence permitting limited copying issued by the Copyright Licensing Agency, 90 Tottenham Court Road, London W1T 4LP.

Any person who does any unauthorised act in relation to this publication may be liable to criminal prosecution and civil claims for damages.

The author has asserted her right to be identified as the author of this work in accordance with the Copyright, Designs and Patents Act 1988.

Published by

PALGRAVE MACMILLAN

Houndmills, Basingstoke, Hampshire RG21 6XS and

175 Fifth Avenue, New York, N. Y. 10010

Companies and representatives throughout the world

PALGRAVE MACMILLAN is the global academic imprint of the Palgrave Macmillan division of St. Martin's Press, LLC and of Palgrave Macmillan Ltd. Macmillan ${ }^{\otimes}$ is a registered trademark in the United States, United Kingdom and other countries. Palgrave is a registered trademark in the European Union and other countries.

ISBN 978-0-333-61340-5

ISBN 978-1-349-27505-2 (eBook)

DOI 10.1007/978-1-349-27505-2

This book is printed on paper suitable for recycling and made from fully managed and sustained forest sources.

A catalogue record for this book is available from the British Library. 
This book is dedicated to the memory of Kate Noel, bright and beautiful daughter of my friend Penny, who died on 12

August 1995, after being knocked down by a car.

She was twenty three. 


\section{Contents}

Acknowledgements ix

A note on terminology $x$

1 FEMINISM AND THE SITUATION OF WOMEN TODAY 1

Women today: the balance-sheet of change 2

Feminist debates 5

2 FEMINIST THEORIES TODAY 8

Equal rights: the 'common sense' liberal approach 9

Capitalism and socialism: the oppression and liberation of women? 16

'Radical', women-centred approaches 25

Black feminism: from margin to centre? 32

The impact of post-modernism 36

Conclusions: feminist theory and political practice today 43

3 GENDER, RACE AND CLASS 45

The language of 'gender', 'race' and 'class' 45

Feminism: a racist, class-based movement? 59

Who is the most oppressed?: from hierarchical to interdependent oppressions 61

Where do we go from here? 66

4 FEMINISM AND THE LAW 72

A male-dominated profession $\quad 72$

Equality with men: employment law $\quad 74$

Equality with men: the criminal law 78

Gender and justice: women's 'different voice' 81

Law in a patriarchal society $\quad 82$

Strategies for change $\quad 84$

Conclusions $\quad 89$

5 POLITICS AND THE STATE 90

Feminist theory and political concepts $\quad 90$ 
Recent political experience in Britain, the United States and Scandinavia

Feminism and the political representation of women

Conclusions: feminist political strategies today

6 THE FAMILY AND PAID EMPLOYMENT

The family

Paid employment

Conclusions: towards a better balance in the interests of all

7 REPRODUCTION

The situation today

Competing perspectives on 'a woman's right to choose' 155

Beyond rights: abortion and feminist debates 161

Conclusions: feminism and the politics of reproduction 170

8 PORNOGRAPHY

Background

Feminists, pornography and the law: an overview

of the debates

What is pornography? 180

Pornography, harm and the oppression of women $\quad 184$

Conclusions: debates and strategies for the

21 st century

9 THE PROBLEM OF MEN

Theoretical starting-points

Men and feminist theory today 203

What is a nice man to do? 210

$\begin{array}{ll}\text { Conclusions } & 213\end{array}$

10 CONCLUSIONS

Further reading 223

Bibliography 228

Index 256 


\section{Acknowledgements}

I would like to thank my colleagues at Huddersfield University for enabling me to have a sabbatical semester to work on this book and for helpful feedback in the Politics Research Seminars. Special thanks to members of the Gender Research Group, to Andrew Taylor, Bill Stafford and Steve Brown for comments on early drafts of some sections, and to Peter Gurney for curbing my metaphors when they galloped out of control. Thanks too to many of the students in my Women, Politics and Society module for their hard work and enthusiasm.

Very special thanks are due to Ruth Lister and Elizabeth Meehan for their constructive comments on the draft manuscript, and to my editor, Jo Campling, for her confident support and patience when I needed to extend my deadlines. Thank you to Penny Noel for advice and references for Chapter 6, to Fran Thurling for the suggestion at the beginning of Chapter 9 and to Ben Enticknap for proof-reading much of the final draft.

Thanks to my friends, without whose practical, emotional and intellectual support this book could not have been written.

And thanks to Patrick and Lucy Bryson for keeping me in touch with reality. 


\section{A note on terminology}

My use of the term race throughout this book refers to socially created identities and structures, not to biological categories. I have decided against putting the word into inverted commas to make this clear, because singling out this one term would seem to pre-judge feminist debates over whether sex and gender are also to be understood in societal rather than biological terms. For a fuller discussion of this, see Chapter 3. 